\title{
A LIBERALIZMUS ARCHITEKTÚRÁJA ÉS AZ ILLIBERALIZMUS DILEMMÁJA ${ }^{1}$
}

\author{
Paár Tamás \\ (Pázmány Péter Katolikus Egyetem)
}

A tanulmány beérkezett: 2019. május 18. - véglegesítve: 2020. január 9.

(Patrick J. Deneen: A liberalizmus kudarca. Ford. Kisantal Tamás. Libri, 2019. Patrick J. Deneen: Why Liberalism Failed. Yale University Press, 2018.) ${ }^{2}$

Az elmúlt év egyik legfontosabb politikafilozófiai eseménye az Egyesült Államokban Patrick Deneen Why Liberalism Failed címú kötetének publikálása volt. Deneen könyvét hosszas viták előzték meg a szerzővel a liberalizmus mibenlétét és értékelését illetően számos orgánumban, a politikai spektrum különböző szeleteit képviselők részvételével ${ }^{3}$ - ennek köszönhetően megjelenésekor már széleskörű figyelem irányult rá. A nyugati világ politikai változásainak következtében pedig egyébként is érdeklődésre számíthatott tézise, miszerint a liberalizmusnak a címben megjelölt bukásáért maga a liberalizmus tehető felelőssé: a liberális politika hosszútávon saját vesztébe rohan.

A könyv egyik nagy erénye összegző jellege: számos olyan kritikát megismétel, amelyek a liberalizmussal kapcsolatban korábban különböző irányokból és különböző szerzőktől elhangzottak. Az általa kifejtett liberalizmuskritikában felhasznált egyes elemek megtalálhatók például a kommunitáriusként elkönyvelt Alasdair MacIntyre-nél és Michael Sandelnél, a konzervatív szociológus Robert Nisbetnél, az amerikai dél eszményét hirdető Wendell Berrynél, a whig Edmund Burke-nél vagy a Deneen által legtöbbet hivatkozott Alexis de Tocqueville-nél, sőt - hogy a lehetô legkorábbi forrásokra is utaljunk -, Platónnál és Arisztotelésznél. A liberalizmus bukásáról szóló fent idézett diagnózisa például azonos a Böckenförde-dilemmával, vagyis azzal a számtalanszor emlegetett paradoxonnal, amelynek értelmében a liberalizmus kénytelen a társadalom olyan tartalékaira támaszkodni, amelyeket nem képes újratermelni. Ezen kívül Deneen olyan gyakran ismételt kritikákkal is él, amelyek szerint például a liberalizmus az emberek alsórendúbb vágyainak és így a középszerüségnek kedvez; ehhez kapcsolódóan megtalálható nála az a republikanizmussal összefüggő nézet is, miszerint a liberális állammúködés elégtelen a polgárok nagyfokú és általános politikai aktivitásának kialakítására, és a (polgári) 
erények kimúvelésére - márpedig Deneen szerint a helyes politikai irány megtartásához ezekre szükség lenne.

A szöveg összegző volta mellett leginkább pamfletjellege dominál, erre utal számos olyan érvelési manővere és retorikai fogása, amelyek sokszor megtalálhatók hasonló politikai múvekben: például nézete klasszikus voltának hangsúlyozása és alternatív, harmadikutas jellegének kiemelése vagy az ellenfelei ${ }^{4}$ közti különbség jelentőségének tagadása. E retorikai fogások közül Deneen esetében az újradefiniálás múvelete a legfontosabb, amit mind a liberalizmussal magával, mind bizonyos intézményekkel és eszményekkel kapcsolatosan megtalálhatunk a könyvben.

Míg különböző szerzők a liberalizmust a szabadság, az (esély)egyenlőség vagy a politikai jogok, az államhatalom korlátozása, esetleg állam és egyház elválasztása felől jellemeznék, addig Deneen ezeket másodlagosnak tartja. Történeti alapon arra mutat rá, hogy ezek az eszmények már a liberalizmus tényleges színrelépése előtt is megjelentek, ezért a lényeget másban kell keresnünk. A liberalizmus mélystruktúrája Deneen szerint végeredményben egy kétkomponensû antropológiában áll (49-50.). ${ }^{5}$ Az első komponenst ebben az emberképben az individuum közösséggel szembeni abszolút primátusa, valamint a választás voluntarista felfogása alkotja. A második komponens az ember természethez és tudományhoz való viszonyát illeti: ez alapján az ember nem része a természetnek, a természet eszköz számára, amelyet a tudomány segítségével kihasználhat.

A liberalizmusnak ez a fajta definiálása elvileg elejét veszi kétféle kritikának is. Az egyik kritika azt veti fel, hogy nem adhatjuk fel a liberalizmus olyan tagadhatatlan értékeit, mint amilyenek az emberi méltóság, a jogegyenlőség, stb. A másik kritika pedig azt hozza föl, hogy azok a fajta erényes közösségek, amelyeket Deneen látni szeretne, valójában a liberalizmus biztosította keretek közt is létrehozhatók, például a korlátozott államnak köszönhetően. A szerző mindkét kritikára úgy válaszolhat, hogy ezek az intézmények (a korlátozott állam, állam és egyház szétválasztása stb.) nem tartoznak a liberalizmushoz, mert időben megelőzik, és valójában az ő eszményei közt is szerepelnek. Ezek a kritikák annak ellenére, hogy valójában célt tévesztenek, mégis gyakran előfordulnak Deneen bírálói közt - mivel újra és újra megfeledkeznek róla, hogy az alapvető kérdés a definícióalkotás megvitatása lenne.

Ami az erényes közösségek liberális ideológia biztosította lehetőségeit illeti, Deneen szerint a helyzet rosszabb, mint azt kritikusai gondolják. A liberalizmus abban hozott újdonságot szerinte, hogy bár a polisz mai megfelelőiként elgondolható ${ }^{6}$ összetartó kisebb közösségeket, illetve a szoros családi, városi kötelékeket nem tiltja, de nem is teremti meg az alkalmat a létrehozásukra. Sőt, egy önkényes döntésként felfogott választásként értelmezi a hozzájuk való csatlakozást, ami pedig eredendően természetes azonosulást kellene jelentsen. Ezzel a liberalizmus minden kötődésünkből laza kapcsolatot te- 
remt, holott stabilitásához ezeknél erősebb lojalitásra épülő kötelékekre lenne szükség - ezért is hullik szét végül.

A laza kapcsolatokért Deneen szemében a voluntarista szabadságfelfogás tehető felelőssé. Itt alapvetően az Isaiah Berlin által negatívnak nevezett szabadságfelfogásról van szó, bár nem véletlen, hogy Deneen inkább azt a terminust választja, amely például Servais Pinckaers teológiájában is domináns: Berlinnel szemben ők a szabadságot úgy értelmezik, hogy annak valami értékesre kell irányulnia. Deneen azt kifogásolja, hogy a szabadságot ehelyett sokan korlátlanként és a választásainkat illetően semlegesként gondolják el, miközben a valódi szabadság csak az lehet, amihez az önkorlátozásban, illetve „önszabályzásban” (123.) jutunk el. Ha az önmagunk számára a természet adta akadályokat figyelembe véve nem szabunk korlátokat, az a parttalanság állapotához vezet, ahhoz, hogy önmagunk szenvedélyeinek leszünk kitéve. Itt érkezünk el Deneen alapintuíciójához. „Két szimpla okból csalóka a korlátok alól történő felszabadítás: egyrészt mert az ember étvágya [appetite] kielégíthetetlen, másrészt azért, mert a világnak megvannak a maga határai. E két ok miatt modern értelemben sohasem lehetünk szabadok." (150.) Az emberi vágyak korlátozásra szorulnak ahhoz, hogy ténylegesen beteljesíthetők legyenek - korlátozásukhoz pedig meg kell tanulnunk az önuralmat, illetve önkormányzást mind az egyén, mind a közösség szintjén. A korlátozás és korlátozatlanság alapvető dichotómiája határozza meg tehát Deneen liberális felfogással szembeni kritikáját.

A méltóság, állam és egyház elválasztása és más, a libereralizmust megelőző, a liberális értékek közt is helyet kapó fogalmak a könyv érvelése szerint eredetileg a korlátozás jegyében álltak, ám a liberalizmussal az egyéni vágyak mind korlátlanabb követésének ideáljára helyeződött át az alapjuk. Így a szabadság fogalmának átértelmezése további újradefiniálásokhoz vezet Deneennél - igaz, ô úgy látja, ezekkel visszatér a szavak eredeti, a modern kort megelőző jelentéséhez, amiket a liberális filozófia forgatott ki magából (41.): az emberi méltóság alapja az új szabadságfogalom lett, és ezzel együtt az emberi jogok, a hatalmi ágak szétválasztása vagy a szabad kereskedelem is már az egyén mind korlátlanabb szabadságát szolgálják.

Szó volt már róla, hogy a liberális berendezkedés fenntarthatatlan és a vesztébe rohan. Mi következik azonban utána? Deneen szerint három alternatíva lehetséges. A Jason Brennan által javasolt út, hogy a liberálisok olyan „episztokráciát" alakítanának ki, amely az emberek liberalizmussal szembeni elégedetlenségét megkerülendő egy általános választásokkal leválthatatlan szúk liberális elitre bízná a kormányzást (184.). Ha ezt végül nem lépik meg a liberálisok, úgy esélyes, hogy az emberek egyre inkább egy „illiberális autokrata” avagy „erős ember"7 iránt fognak vágyakozni, és egyre inkább ilyen jelölteket juttatnak hatalomra. Deneen szerint egyik kimenetel sem kívánatos, ő egy harmadik lehetôségben látná a helyes utat. 
Liberális antidemokrácia és autoriter illiberalizmus helyett úgy tûnhet, hogy valamiféle önkormányzásra épülő illiberális demokráciáról lenne szó Deneennél. Azonban egyrészt mivel különbséget lát jó és rossz (vagyis autokratikus) antiliberalizmus között, másrészt szerencsétlen aktuálpolitikai konnotációk elkerülése végett az „illiberalizmus” helyett érdemes egy deneeni kifejezés, a „humánus posztliberalizmus" ${ }^{\prime 8}$ címkével illetni ezt az alternatívát. Ez a terminus azáltal, hogy a liberalizmushoz képest határozza meg magát, már azt is magában látszik foglalni, hogy ez az alternatíva beépíti a liberalizmus vívmányait és tanulságait is (vö. pl. a posztmarxizmus marxizmushoz való viszonyát). Erre utal Deneennél annak hangsúlyozása, hogy nem csupán egy múltbéli politikai helyzetet kíván restaurálni, és nem kíván úgy tenni, mintha a liberalizmus meg sem történt volna (37., 211-215.), mivel szerinte a posztliberális kornak is el kell ismernie azt, ami a liberalizmusból jogos, mint amilyen a méltóság és az igazságosság követelése (210-211.).

Âm amikor Deneen a liberalizmus értékelendő vívmányairól beszél, hovatovább arról, hogy a liberalizmus követeléseit (sőt, elvileg még szabadságkoncepcióját is! - ld. 211.) beépíti a humánus posztliberalizmusba, valójában olyasmit tesz, amit a saját maga adta meghatározás kizár. Hiszen Deneen nem ismerheti el a szabadelvúség inherens értékeit, mivel szerinte a liberalizmus mindössze a voluntarista individualizmusból és az ember és a természet elválasztásából áll. Vagyis csak olyasmiből, amit Deneen tagad - és minden mást, ami a liberalizmushoz látszana tartozni, csak egy régi ideál eltorzulásának vél. A liberalizmus érdemeit így elsősorban abban ismerheti el, hogy képviselői rámutattak arra: a preliberális kor nem tartotta magát (a gyakorlatban) a saját maga által (elméletben) vallott értékekhez. Tehát amennyiben aláírná Deneen, hogy a liberalizmusnak általa is elismert jó következményei voltak, az a liberalizmus esszenciájától független, esetleges fejlemény lehet csak. Az ilyen eredmények azonban a könyv elemzései alapján gyakran vegyülnek a liberalizmus szimptómáival. Így például, hogy bár Deneen elismeri azt, hogy a liberalizmus dominanciájának köszönhetôen a női egyenjogúság helyzete jó irányba változott, ugyanakkor különböző feministák és marxisták társaságában kifogásolja, hogy a nők elsősorban a kapitalizmusnak való kiszolgáltatottságukban váltak egyenlőkké a férfiakkal (215.). Vagyis úgy tûnik, hogy szerinte az, ami ténylegesen jó a hasonló hozadékokból, az a liberalizmus nélkül is elérhető lett volna. Az olvasónak nem véletlenül támadhat az a benyomása, hogy a liberalizmus végeredményben csakis rossz dolgokért tekinthető felelősnek. Mindez pedig rávilágíthat a könyv által felkínált liberalizmusdefiníció nehézségeire.

A liberalizmus kétkomponensü meghatározása a könyv sarkalatos pontja, és külön tanulmányt érdemelne megvitatása. Mint láttuk, Deneen szerint a liberalizmus csakis azzal azonosítható, ami első megjelenésekor (gyakorlatilag Hobbes és Locke korában) újdonságot jelentett. A definiálás általános problémáival együtt ezzel szemben felmerül többek közt az az ellenvetés, hogy el- 
vileg az is lehet egy izmusnak esszenciális része, ami tényleges színrelépése előtt már bizonyos korábbi gondolkodóknál megjelent. (A kereszténység például nem lesz kevésbé lényegileg monoteizmus attól, hogy már Krisztus előtt is találkozunk a történelemben egyistenhittel - így pl. közvetlenül a zsidó vallásban.) Az inverz probléma, hogy amennyiben a Deneen által a liberalizmus lényegi részeiként megjelölt komponens bármelyikét megtalálnánk a liberalizmus protoliberálisnak nevezhető előfutárai előtt (amire jó esély van például a szofistáknál vagy az epikureusoknál), úgy eszerint azt sem tarthatnánk a liberalizmus lényegi részének. Annak állításából, hogy ez a két komponens a modernitásban megjelenő liberalizmus egyedi jellemzője, kitûnik: Deneen a megelőző politikai gondolkodást egységesebbnek tünteti fel, mint amilyen a valóságban volt.

A történeti fejlemények alapján alkotott definíciójának megfelelően Deneen egy liberalizmust megelőző „klasszikus hagyományt” is kijelöl, amely ugyanennyire leegyszerüsítônek tünik. Deneen gyakran él olyan fordulatokkal, hogy "az antik gondolkodók úgy tartották” vagy általánosságban az „antik és keresztény felfogásról” ír. ${ }^{9}$ Még többször szól „klasszikus és keresztény hagyományról", amellyel kapcsolatban legalább megjegyzi, hogy fejlődésen ment keresztül. ${ }^{10}$ Ám ez is azt látszik sugallni, hogy a fejlődés egyenes vonalú volt, és egységes konklúziókhoz vezetett a keresztény gondolkodóknál - ami azonban korántsincs így. (Egy szélsőséges, Deneennel és a liberalizmussal is ellentétes tanokat hirdető példát találhatunk Robert Filmer személyében.) Deneen e retorikus egyszerúsítésének köszönhetően válik szembeötlőbbé a legtöbbször megnevezetlen „klasszikus” gondolkodók és a liberalizmus kontrasztja.

A múlt politikafilozófiájának ebből a leegyszerúsítéséből is látszik, hogy Deneen könyvének a filológiai pontosság nem tartozik az erősségei közé. A könyvben a prototipikus liberálisként kezelt Locke-nál például számos olyan tendenciájú érvet is megtalálhatunk, amelyek a Deneen által kifogásolt hedonista önzés (amit Deneen egy újabb pontatlansággal „utilitáriusnak” nevez) ellen hatnak, és hogy Locke múveiből inkább a klasszikus hagyomány folytatását vagy egy új ideológia megkezdését olvashatjuk-e ki, az korántsem egyszerû kérdés. ${ }^{11}$

Deneennek Locke mellett Amerika alapító atyáival kapcsolatban is számos kifogása van, közülük ebben a múben Madisont kritizálja hosszabban, mivel Madison célkitûzése (legalábbis Deneen értelmezése szerint), hogy az emberek a helyi önkormányzatok helyett a központi államhatalommal azonosuljanak. Ez utóbbinak elsőszámú célja pedig az emberek diverzitásának növelése és a polgárok érdekeik mentén történő szegmentációja, hogy ne alakulhasson ki olyan érdekszövetség, amely felboríthatná a kialakult rendet. Mint azonban már mások is kimutatták, Deneen nem számol azzal, hogy Madisonék a Föderalista különböző pontjain nem egy, hanem - némileg ellentmondóan - három fő célt is tulajdonítanak a központi kormányzatnak, amelyek egymást árnyal- 
ják. Leegyszerúsítése ellenére Deneen hermeneutikája nem zárja ki figyelemre méltó olvasatok megszületését, így például egy másik hosszabban tárgyalt ellenlábas, Mill értelmezésekor szóba kerül a rabszolgaság melletti érvelése (6970.) - de vele kapcsolatosan is érdemes megjegyezni, hogy az már nem kap kellő figyelmet, hogy Mill (vagy épp az amerikai alapító atyák) egy erényes polgárság megléte esetén tartotta megvalósítandónak szabadelvú politikáját.

Ha a történelmi és eszmetörténeti előzményeket Deneen szemüvegén keresztül vesszük szemügyre, akkor a liberalizmus fent ismertetett lecsupaszított definíciójából adódóan aligha látjuk úgy, hogy „a liberalizmus [...] talán egy szükséges lépcsőfok", amely fontos tanulságokkal szolgált - miközben ezt maga a szerző veti fel (188.), jóllehet más szemszögből igenis üdvös fejleménynek tekinthető. Ha arra tekintünk, hogy a történelemben a különböző rendszerek mindig egyfajta csömörhöz vezettek, arra a konklúzióra juthatunk, hogy az emberi természet ellentmondásossága magával vonja a politikai berendezkedés változásai utáni vágyat. Bár Deneen állításai egy filozófiai antroplógia alapjain állnak, mégis vakfolt számára ez az antagonizmus, az ember „társiatlan társiassága". Így azzal nem vet számot, hogy a liberalizmusban meglévő individualizmus az ember olyan vágyaira apellál, amelyek nem feltétlenül nevezhetők alsóbbrendûnek: ilyen a közösségtôl való különbözés, az önállóság és egyediség vágya. Ezek nem csak tényszerūen tartoznak az emberhez, de sok esetben szükség is van rájuk ahhoz, hogy az ember függetlenedjen bizonyos közösségek káros befolyásaitól, és időnként a legnagyobb teljesítmények előfeltételei is. Ezek az igények gyakran az emberbe kódolt más ösztönök riválisai, mint amilyen a valahova tartozás, az azonosulás és a szolidaritás vágya. A „társiatlan társiasság” e problémájára kínál a liberalizmus egy többé-kevésbé adekvát, még ha tökéletlen és nehezen is fenntartható politikai feloldást azzal, hogy lehetôvé teszi az egyén elkülönülését, ugyanakkor meghagyja az utat a közösségekkel való azonosulás előtt.

Hogy a Deneen kínálta alternatíva az individualitás ellentétes irányú alapvetô vágyait mennyire tudja befogadni, az még elválik a társadalomkritikán túlmenő, az összetartó kisközösségekre építő konstruktív javaslata bővebb kifejtésének fényében - ám egy aggasztó tendencia, a többségi zsarnokság problémájának lekezelése, kétségeket támaszthat vállalkozásának e kérdést illető sikerességében.

Az egyénre nehezedő társas nyomás többek közt akkor válik problematikussá, ha a fenyegető közvélemény eluralkodik - ez a többség zsarnokságának esete, amely szoros összefüggést mutat a reflektálatlan előítéletek kérdésével. Amellett valószínúleg szükségtelen ehelyütt érvelni, hogy reflektálatlan előítéleteink sok esetben hibásak lehetnek, és hogy sokszor e hibák közé tartozik az egyes csoportokkal, illetve kisebbségekkel szembeni irracionális ellenszenv. Ez kettős problémát jelent: az előítéletek felülvizsgálata nélkül egyrészt valószínúbben követünk el elméleti és praktikus hibákat (vagy egyenesen vétke- 
ket), másrészt kialakulhat a többségi társadalom elnyomása az előítéleteikben nem osztozó vagy tôlük más tekintetben (pl. nem, bőrszín, vallás) különböző kisebbségek ellen. A Deneen által nagyra tartott Tocqueville például épp ezt a kérdéskört látja az egyik legfontosabbnak az amerikai demokráciával kapcsolatban. Deneen azonban Tocqueville-re épp ebben a kérdésben nem támaszkodik - annál inkább Edmund Burke-re.

Deneen hivatkozásai Burke-re több kérdést is felvetnek, mivel főleg azokat a szöveghelyeket idézi tőle, amelyek szerint helyes előítéleteinkre támaszkodni (174-175.). Többek közt Strauss ${ }^{12}$ és MacIntyre ${ }^{13}$ is amellett érveltek, hogy ezek a burke-i passzusok ellentétesek a racionalitással. Ahogy Strauss fogalmaz: Burke-nél megfigyelhetjük „,az érzelemnek és az ösztönnek egyfajta fölszabadítását, illetve az ész egyfajta leértékelését" ${ }^{14}$ Nem feltétlenül Strauss és MacIntyre értelmezése a mérvadó Burke mondandójával kapcsolatban, azonban Deneen itt többször is az irracionális, átgondolatlan szokások védelmében szólal fel azok kritikusai ellen (vö. 44., 174.), és erre használja fel Burke meglátásait is - mintegy kivédendő a racionális reflexiót mint ártalmas tevékenységet. Deneen ezzel kapcsolatban hivatkozhatna arra, hogy véleménye szerint a deliberáció, tehát elvileg valamiféle reflexió a helyi közösségek önkormányzásának fontos része - viszont ahhoz, hogy ez a fajta deliberáció ténylegesen védelmet nyújtson a vázolt veszélyekkel szemben, racionalitás-alapúnak kellene lennie. Ám pont ezt zárja ki a burke-i előítéletnek mint irracionális előítéletnek az átgondolással szembeni védelmezése: ha egy diskurzus ilyen értelemben véve burke-i, az megfeleltethető a szofisztikus retorikai manipulációnak. A deliberáció ilyen esetekben észérvek helyett az ember vágyaira vagy hatalmi viszonyokra apellál.

Deneen számos helyen tárgyal olyan témákat, amelyek a többség zsarnokságával összefüggésben állnak, ám jellemzően vagy úgy veszi, mintha ez a nehézség az általa preferált közösségekben magától megoldódna (vö. 117.) vagy azt sugallja, hogy más értékek kellőképp ellensúlyozhatnák (vö. 203-204.). A legközvetlenebbül akkor érinti ezt a kérdést, mikor arról ír: „Mill a közvélemény zsarnokságától félt, amely szerinte a szokásokban fejeződik ki. Burke szerint azonban a társadalmi »újítók « között sokkal erőteljesebb a zsarnoki hajlam, és éppen az előítéletek fékezhetik meg e törekvést." (175.). Ezzel a Deneen által elfogadott érvvel kapcsolatban nem csak az a probléma, hogy véleményes (a többség számára például nyilván nem számít zsarnokságnak, bármilyen előítéletekkel is él), és hogy hiányzik az alátámasztásául szolgáló statisztika. A lényegi probléma ugyanis az, hogy a valószínúség itt másodlagos, hisz a többségi vélemény és az elöítéletek szülte zsarnokság problémája nagyon is valós és súlyos - nem szerencsés pusztán annak felhozásával relativizálni, hogy vannak hasznos elöítéletek is. Ha a racionális felülvizsgálást kizárjuk és csupán az irracionális előitéletek és szokások maradhatnak támaszaink, amelyek könnyen lehet, hogy minden esetben ugyanazt a részre- 
hajlást támasztják is alá - akkor a probléma megoldásában minden segítség nélkül maradunk.

Ahogy Deneennél keveredik a deliberáció kívánalma az előítéletek dicséretével, úgy keverednek a könyvben az önkorlátozásra és erényes önkormányzásra szólító, megfontolásra érdemes részek a retorikai fogásokkal, a túlzó állításokkal és a felszínes közhelyekkel. Így Deneen azt állítja, hogy a liberalizmus az egyik valaha volt legegyenlőtlenebb rendszer (27. - itt nyilván számítana a mintavétel mérete, ám ha a mai liberális államokat rabszolgatartó társadalmakkal és harmadik világbeli királyságokkal versenyeztetnénk, aligha lennének az élbolyban), máskor pedig azt állítja, hogy a liberalizmus csupán a platóni értelemben vett nemes hazugság legtökéletesebb megvalósulása - amit már a haszonélvezői is elhisznek (ezzel kapcsolatban pedig érdemes meggondolni, hogy vajon ha ők is elhiszik, nevezhetjük-e még hazugságnak, és hogy vajon a kommunizmust nem ugyanilyen hazugságnak kellene-e tartanunk). A túlzások mellett pedig olyan elcsépelt szólamokkal is találkozunk a könyvben, mint az „internet a szó szoros értelmében elbutít minket” (116.), vagy hogy ma már alig vagyunk képesek egy órán át egy helyben ülni és nyugodtan olvasni egy könyvet vagy elmélkedni (33.) - ami valójában legkésőbb Pascal óta elmondható a nyugati emberól.

Szerencsére Deneen legtöbbször a kevésbé eredeti liberalizmuskritikákat is eredeti módon képes kifejteni és új összefüggésbe helyezi őket. Ezeken kívül pedig újszerú vagy legalábbis ritkábban hallott megfigyeléseket is tesz, amelyek az egyes fejezetek magvát alkotják; ilyen például, hogy a liberalizmus cinkos a természet kizsákmányolásában, hogy felelőssége van a humán tudományok hanyatlásában, hogy individualizmusa az erős államhatalomnak kedvez, vagy hogy egy újfajta elit malmára hajtja a vizet. Deneen alapvetően jó kultúrkritikai vénával is rendelkezik. Ennek köszönhetően csak ritkán találkozhatunk nála a fentiekhez hasonló banalitásokkal, máskor érdekfeszítő elemzéseit olvashatjuk tőle bizonyos reklámoknak, filmeknek, sporteseményeknek, egyetemi mottóknak és az épített környezet változásainak.

A könyv végül számos összefüggést és részletkérdést kifejtetlenül hagy, különösen, ami Deneen liberalizmussal szemben felkínált alternatíváját illetné. A szöveg azzal a meglátással ér véget, hogy egy új elméletre van szükség, amit egy új gyakorlatnak kell megelőznie. Ez magyarázhatja a kifejtés hiányosságait bizonyos pontokon, és azt is, hogy a könyv azt sugallja, mintha egyes problémák maguktól megoldódnának. Persze Deneen már itt is egy elmélet megalkotásába kezd bele, amely a helyes társadalmi attitúdöket vizsgálja, így alapvető kritériumokat megad ehhez és nyilván inspirálni is kívánja a megfelelő gyakorlatok létrejöttét. Ezért teoretikus nehézségei nem vehetők teljesen félvállról, különösen, mivel a könyvben felvetett változtatás - a liberalizmus elvetése - meglehetôsen radikális. Egy teljesebb elmélethez Deneennek legalább tekintetbe kellene vennie olyan jogos félelmeket, amelyek a liberálisokat 
motiválják. Elsőként el kellene vetnie a reflektálatlan előítéletek apológiáját ahhoz, hogy a helyi közösségek racionális deliberációjának megfelelő lehetőségét megadja. Ezen kívül azonban még mindig megmaradna az a nehézség, amit a "társiatlan társiasság" kantiánus terminusával neveztem meg, ami itt arra vonatkozik, hogy egy politikai közösség kívánatos esetben megfelelő módon bátorítaná a részvételt az imént leírt racionális politikai deliberációban és általában a közösség életében, ám az ezektől való függetlenedést is elfogadható mértékben lehetővé kellene tennie. A jelen állás szerint nyitott kérdés, hogy a Deneen által preferált „humánus posztliberális alternatíva” képes lesz-e mindezeknek a kritériumoknak megfelelni és megtalálni az emberek közösségi és egyéni törekvései közötti ideális egyensúlyt.

\section{JEGYZETEK}

1 A szöveg az Emberi Erőforrások Minisztériuma ÚNKP-18-3-III-PPKE-39 kódszámú Új Nemzeti Kiválóság Programjának támogatásával készült.

2 A recenzió elsősorban az eredeti kiadásra támaszkodva készült.

3 A vitáról ld. Szilvay Gergely: Egy amerikai vita a liberális demokráciáról. In: Pogrányi Lovas Miklós (szerk.): Konzervatív reneszánsz az Egyesült Államokban. Budapest, Századvég, 2016. Paár Tamás: Amerikai Kommunitarista Államok? Lehet-e egy közösségelvű egyúttal amerikai konzervatív is? Kommentár, 2018/2. Az utóbbi cikk bővített változata hamarosan elérhetővé válik, az ezzel kapcsolatos helyreigazítást ld. a Kommentár folyóirat 2018/3-4. számának 74. oldalán.

4 Itt leginkább az amerikai liberálisokról (Deneen őket progresszíveknek is nevezi) és konzervatívokról van szó (utóbbiakat klasszikus liberálisként jellemzi).

5 Az oldalszámok a magyar kiadásra vonatkoznak.

6 Vö. 17,. 189-190., 210., 220., 226. oldalak.

7 Az eredetiben: „illiberal autocrat” és „strongman” (178.), a magyar fordításban: „illiberális zsarnok” és „erős uralkodó" (205.).

8 Az eredetiben: „humane postliberal alternative” (182.), a magyar fordításban: „posztliberális humanista alternatíva" (209.).

9 Vö. 123., 138-140., illetve az eredetiben 100., 115.

${ }^{10}$ Ld. 37., vö. az eredetiben 19.

${ }^{11}$ Vö. Leo Strauss: Természetjog és történelem. Budapest, Századvég, 1999. 142-181. Strauss amellett érvel, hogy Locke ellentmondásai esetében mindig a radikálisabb, modern oldalt kell komolyan vennünk, míg Deneen vitapartnerei ez ellen érvelnek.

${ }^{12}$ Ld. uo. 206-223.

${ }^{13}$ MacIntyre számos helyen kritizálja Burke-öt, magyarul ezek közül ld. Alasdair MacIntyre: $A z$ erény nyomában. Budapest, Osiris, 297-298. Továbbá uő: Az etika rövid története. Budapest, Typotex, 2012. 313-317.

${ }^{14}$ Ld. Strauss: Természetjog és történelem. 217. 